\title{
RADICAI THACHER
}

A SOCIALIST, FEMINIST, AND ANTI-RACIST JOURNAL ON THE THEORY AND PRACTICE OF TEACHING

Annals of Academic Life: An Exemplary Tale

by Louis Kampf

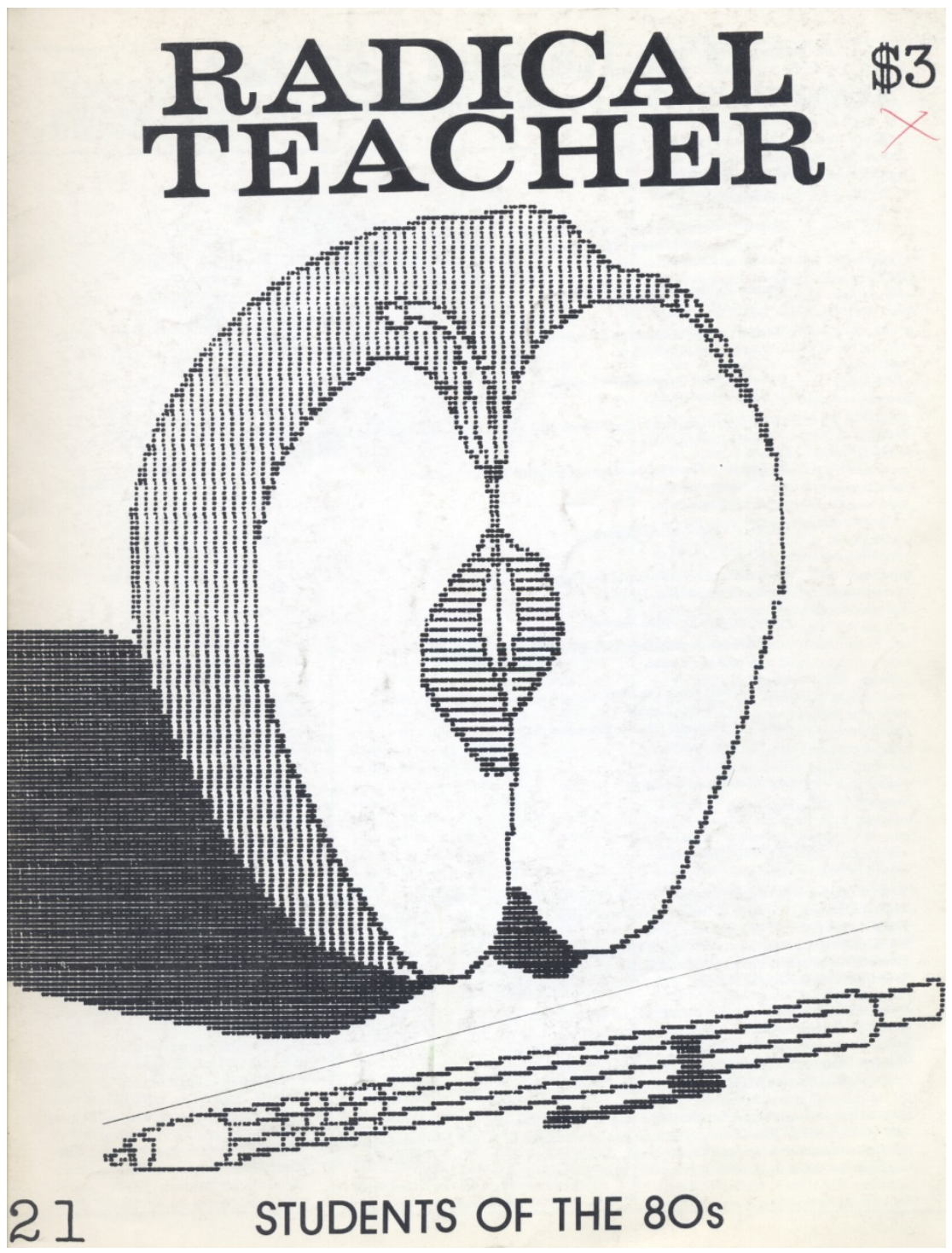


$\mathrm{T}$ he narrator of the following vignette is not to be mistaken for the author. Though the tale appears to be autobiographical, it must be a fiction. Academic institutions, as we know, are the repositories of rationality. Professors have been bequeathed the patrimony of the Enlightenment. Such evidence indicates that the events described below could not possibly have happened.

$$
* * *
$$

The faces are those of ten-year-olds playacting at seriousness. They belong to my colleagues, the tenured members of the English department. Alas, their performance is not staged for the benefit of parents at a grade school's annual Christmas play.

"It's the most agonizing decision I've ever had to make," mumbles Remington. I look for a trace of irony in his face, but find only the grimness of domestic tragedy. He runs his fingers through his neatly trimmed hair, directs the hint of a boyish smile my way, and lets his almost double chin sink onto the knot of his tie. Seated around the oval seminar table, his colleagues nod their heads knowingly. They too are in pain. Their brows are furrowed, their lips tightly shut, their eyes intently fixed on stacks of recommendations ominously marked "confidential."

"I've been up most of the night," Remington continues, "and though I really like Leah, I cannot approve of her scholarly methods. When she quotes from original manuscript sources it's done in the original spelling. This is very misleading for future scholars. She really should modernize the spelling." I'm facing Remington and begin to smile. I'd really like to double over with laughter, but Leah Scott's future is at stake, so I control myself. I glance at my colleagues. Maybe - just maybe - someone will giggle. No. Lips are even more compressed, brows more deeply furrowed. Remington does not respond to my smile. He plays obsessively with the buttons on the vest of his double-knit suit. Leah Scott's many publications - two books, articles, reviews, editions - lie scattered around the table. They draw little attention as this gathering of scholars arduously culls nasty little snippets from the file of confidential recommendations. My colleagues, after six hours of squeezing out scholarly reflections as profound as Remington's, vote to deny Leah Scott tenure.

$$
* * *
$$

That morning I had gone through my breakfast ritual of envisioning apocalypse. The newspapers were my book of visions: murder and destruction in El Salvador, the planned deployment of nuclear missiles, starvation in East Timor, a rape in my neighborhood, Reagan's cutback of medical services for old people. Death, destruction, and mean-spiritedness on a global scale. Neither my heart nor brain found much room for worries about Leah. After all, nearly everyone (except Leah) had known for at least two years that she would be fired. My colleagues could not officially say that a feminist doing women's studies was not to be taken seriously, but reasons would be found. And we shall sit around a table (do they sit around similar tables in the Pentagon, I wonder) and apply our collective interest to finding them. Six hours that might be spent on halting nuclear madness; on enlightening students; on enjoying oneself; on acts of generosity. As I savor the flavor of a particularly tart grapefruit, I know what the scene will be, and I can barely get myself in motion toward school.

Six hours! I walk into the meeting room beginning to feel ashamed of my revulsion. It's not six hours on an assembly line. It's not six hours correcting compositions. It's not six hours spent preparing lectures about books I do not want to teach. In fact, while several of my friends are unemployed, I have a plush job at an elite institution. I teach what I want to teach. There's an occasional struggle over that, but since I'm tenured I can afford to put up a fight against pesky requests from the curriculum committee, and usually get my way. My hours are not overly long. I have a sense of my own competence as a teacher, and my students, who are mostly intelligent and nice, respond to me in class. I have a good time with them, and some learning does go on. In various pockets around the school there are a few faculty members I respect and have affection for. Working with them enlarges my spirit. They have supported me when I was in trouble, and they will do so again. We have enjoyed each other's company at lunch, across a seminar table, at demonstrations, and in jail. I teach at an elite institution involved with the monstrosities I read about at breakfast, yet I enjoy the comfort of doing political work with comrades in the school's socialist group.

But on this particular morning I would rather stay home and vacuum the living room rug.

$$
* * *
$$

I creep away from the meeting. My brain, I am convinced, will never again formulate a coherent idea. Clarity is my goddess; at the moment, I cannot envision her. In an hour I shall be teaching "Contemporary Issues in Politics and Ideology" to students who would like to do something decent with their lives. We'll discuss underdevelopment in Central America, and how to support the popular forces in El Salvador. I feel in communion with these young people. Their concern pricks my conscience. Soon their expectant looks will fill me with anxiety: they hope for so much more than the mechanical transfer of knowledge. How can I possibly meet their expectations? Perhaps I can't. But right now anxiety fuels my desire to make the attempt. When 1 walk into class I shall be a teacher, not an educational bureaucrat; the professor will feel connected to the rest of me. Meanwhile, Leah stays on my mind.

I glance at some lecture notes, but memory interferes and reaches back to the sixties.

$$
* * *
$$

Remington, a new instructor, has a beard so scraggly it looks like it's been pasted on. Unkempt hair hangs down to his shoulders. His smile hints irony but still tells me he is alive with passion. While he was in graduate school, Remington was arrested twice for participating in sit-ins. Since coming here he has given much of his time to working with anti-war groups. Remington's outrageous sense of humor gives his militance a rare ebullience. He 
can double me over with laughter while we're trying to dodge a tactical policeman's oversized club. His inventiveness is at the edge of the surreal, spilling out ideas, wisecracks, analyses of Shakespeare or Dylan. His freakiness is tempered by an unfailing rationality.

Where have you gone, Remington? "I do not believe in equal opportunity curricula," he told me a few days ago, when I asked him why there were no women authors in the "Masterpieces of Western Literature" course. Remington does scholarship so wretchedly conventional, so dull, it nearly embarrassed the administration into denying him tenure. As head of the curriculum committee he worries whether "Popular Narrative" might be used as a catalogue entry for both "Science Fiction" and "Fantasy Fiction." How few hours I spend in class. Leah will appeal her firing, and I shall have to work in her support. More meetings. Political struggles quicken my pulse, and ordinarily make me feel as if I'm giving history a small shove. But there is no joy in butting heads with my colleagues; they simply won't butt. No issue is ever met head-on, and I find myself haggling not over ideas or values, but over formalities. If Leah's head is to be saved from the chopping block, it will be by the grace of the good god Procedure. I know: a democracy can work only if consistent procedures are applied equally to all. And so I'll spar with my colleagues in this ghostly match where all is form and nothing substance; where a real issue - contempt for feminist scholarship - will have to be ignored; where neither they nor I will say what we think

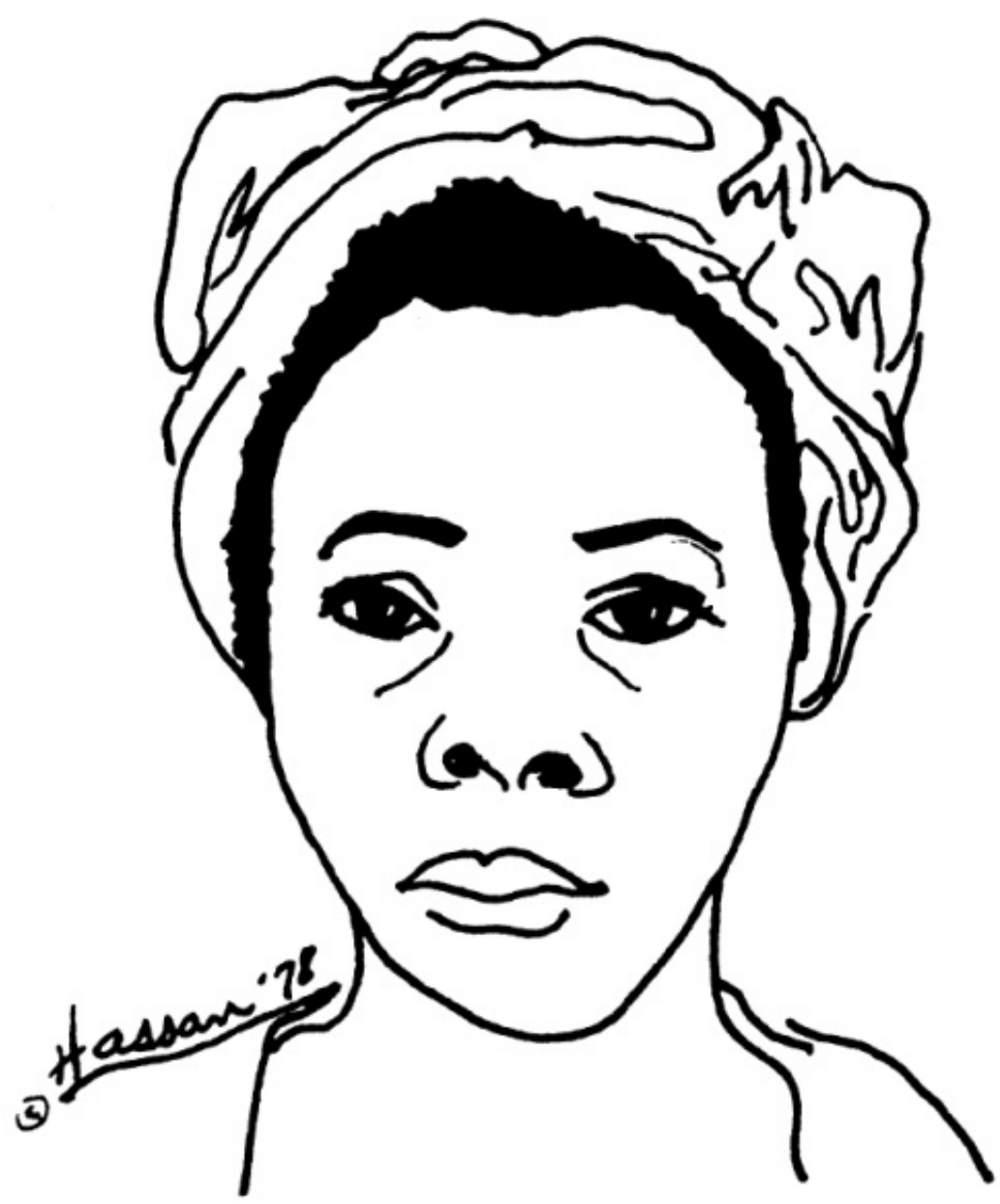

does he shut off his imagination? Why doesn't he explode? No doubt, he has attained the peace that passeth understanding, since God is a living presence for those who follow acceptable scholarly procedures. Such peacefulness allows him to deny Leah tenure for using early English spelling.

$$
* * *
$$

Only half an hour until I'm restored by the "Politics and Ideology" class. But my musings have nearly turned that prospect to ashes. What am I really doing in that class? Anything more than providing future Remingtons with a little room to breathe? Right now I do not want to be here. My institutional life, after all, is composed of more than the of each other. Though furious with myself for hiding, I maintain a politic silence. The faces of nearly all the men seated around the table are hidden behind nearly trimmed beards. The features of one colleague, a woman, are masked by a permanent smile which threatens to crack her jaw; I'm sure it will be there the moment Reagan pushes the atomic button. We are the guardians of the eternal verities, yet never speak our private truths. I'm part of the act, a performer playing to the demands of institutional life.

I look at my watch. Sixteen minutes till class starts. I try to put my opening remarks together, but my thoughts fade to Saul Durling, one of my bearded colleagues with tenure. Saul looks like an obsessed chassid lost in the Ivy 
League. Several years ago, while being interviewed for his job, he sidled up to me, and in a staccato jabber confided that he had been heavily influenced by my writing. What, I wondered, have I wrought? "Perhaps too heavily," he added mysteriously. Soon after he got hired, he came into my office, closed the door ostentatiously, and urged me to teach black studies. He assured me that I could do it a lot better than any black person the department might hire. "I would be very offended," he explained, "if I were forbidden to teach Milton because I'm Jewish." I began to argue, but stopped in mid-sentence. He knew what I would say; I knew what he would say; we would dance our dance and I would be left in a rage. "Hear me," he nagged, "I often feel that you're not discussing these very serious matters with me. At least (grinning) you should tell me I'm full of shit." I yielded: "All right, you're full of shit."

I look back and wonder about my passivity. I avoided the argument because Durling's intellectual stance, his very personality, offend my sense of what a literary intellectual ought to be. With great hesitation I decided to become a teacher of literature and ideas because I believed that intellectuals spend their time not dancing verbal dances, but moving ideas and history forward. What is the point of one more stupid academic hassle? My inspiration had come from Alexander Herzen's memoirs, from Diderot, from Virginia Woolf s literary essays and reviews. And there I was about to turn an important issue into academic nit picking with Durling.

I feel depressed. Poor me. I have a nifty little job at a big famous place, but I feel depressed. A contradiction. For years I've written articles telling people that universities are not the guardians of the critical tradition of the Enlightenment, but the ideological servants of ruling elites. So why do I act as if it's news? When I have to deal with this truism in the flesh and bones of my professional life, I nearly boil over with resentment.

I go off to class. Students scramble by me in the halls. One who has the maddened eyes of Alexander Haig tries to stare me down. I wonder how many will be complicit in the planning of nuclear holocaust or the economic strangulation of millions. How can I, a teacher, hope to change this? What impact can even the best course have? My depression deepens as I walk into class. On this particular day, teaching these very decent students about political possibilities does not brighten my spirit.

I feel cheated. I began teaching this course, which is not part of the English curriculum, during the 1960s. It had been a small part of the challenge to academic dogma initiated by radical students. Here in this class, I said to myself, I'm acting out the role of critical intellectual. I'm engaged with the world. These ideas will matter in the struggle for social change because they are being carried on the wave of a great social movement. The students and teachers who were trying to invent a more rational curriculum gave me hope for the possibilities of education. This course is one remnant of that hope. So when the small monstrosities of a departmental meeting dampen my pleasure in feeling like a true heir of the Enlightenment, I feel depressed. This, I tell myself, is not the life I wanted to lead. In spite of my pretensions, I am just one more hod-carrying professor.

$$
* * *
$$

The class is over. After several minutes of feigned interest in the students' heated discussion, I wander toward my office. I feel separated from everything around me: people pass me like ghosts; the massive stone buildings seem outlines drawn without perspective. The only reality is a bitter memory: the meeting that decided Leah was a malignancy to be removed. Here are the fruits of the Enlightenment: humanity must be protected against the dangers of improper scholarly procedures.

Having felt dangerously exposed in the classroom, I enter my office like a bird returning to its nest. I sit down on my swivel chair, and whirl around to gaze at the books - shelf on shelf of them. Why don't I give them away? What reassurance do they give me? Do they certify me as a man of deep knowledge? My mocking reflections are interrupted by Samuel Smith, who has just wandered in. Smith is handsome, his eyes are frozen in perpetual amusement; he dresses in discreet versions of the latest styles. He is the only black person in the department. He was hired because Andover, Amherst and Yale had given him the words my colleagues wanted to hear. He saw The Deerhunter last night, and wants to discuss its structure of images. I observe that The Deerhunter is part of a movement to falsify the history of America's war against Vietnam. He listens patiently, then says he's not really interested in such matters. Smith also has an idealized notion of what a literary intellectual ought to be. It's different from mine. He sees himself as a civilized gentleman discussing the arts, frequenting sophisticated bars, leading a life of elegant comfort. He plays this role well, avoiding the appearance of academic seediness. Hassles over departmental policy buffet his image of the academy as a haven for humanistic literary discourse. His experience in the department has led him to conclude that the academic game isn't worth the effort. In the fall he will begin law school: it takes money to be truly civilized. After three years, the living will be easy. I wonder why Smith seeks me out so often. Is it because for me the living is, in fact, easy? In Smith's eyes I do lead a civilized life. My deepest concern does not seem to be whether the introductory course will be structured around genres or historical periods. Who will be the next department chair? I don't give it much thought. I have tenure, travel, discuss the arts with some knowledgeability. I am, in short, cultured. No wonder I feel depressed. When Smith leaves for law school will Durling once again ask me to teach black studies?

$$
* * *
$$

When I get home I head for the kitchen. After taking my first sip of pernod (Did Sartre soothe his nerves similarly after a rough day at the Ecole normale superieure?) I begin the intricate task of preparing dinner. Dicing the eggplant for the pasta sauce, my tension recedes as I look forward to the pleasure of my friends and comrades savoring the robust and complex beauty my labor and the tradition of Sicilian cooking have produced. 
After dinner, lingering over a glass of wine, we discuss tomorrow's demonstration in support of the Salvadoran rebels. I find it needs work to convince myself to go. Each demonstration, each meeting, each phone call urging a friend to sign a petition seems like a distinct event. Each demands a new expense of spiritual energy on my part. No compelling historical design urges me to plunge into the next task. Work in school, I reflect, is just one more piece in the political puzzle I can't put together. Nearly every moment I must convince myself that the academic routine is leading - somewhere. Am I really pushing the boulder any further up the hill? Will sitting through one more meeting to save Leah's job make the misshapen colossus where I earn my living a more humane workplace? I think so. But then I don't feel sure. Doesn't the battle (grandiose word!) involve a small attempt to control the conditions of my work? It does. But since I teach at an elite institution, there is no union. So the battle over someone's job is carried on in near isolation; it threatens to turn me into a crank. Meanwhile, there is the demonstration I might be working on.

I swallow the last bit of wine. The dishes need to be washed. There is a class to prepare, an essay to be polished, a phone call to be made to a friend about the demonstration. If I do my work with resolution, there might be time to catch a late movie. 